\title{
The Emancipatory Struggle
}

\author{
Madison Trusolino ${ }^{1}$
}

Violence used for the purpose of protest is often heavily contested. Common uses of violence during a protest such as violent destruction of property, the clash with the police and the screams and shouts of chants are often questioned and thought of as unnecessary, but the resort to violence shows the hidden message: that there are limited options outside of violence to meaningfully oppose the state. The small portion of protests that are allowed by the government in their right to free assembly give the illusion that the protester is participating in a free and open forum for democratic discussion. Like being given the right to vote, the right to strike or participate in and organize peaceful assemblies keeps the protesters in the confines of the system. I argue that in order to truly reach emancipation the protest must be an act of breaking free from the system. The protest must do what is outside of the law, protesters must retaliate against their rights and embrace the violent nature of their protest uniting against oppression in the emancipatory struggle. I will begin by defining and elaborating on the emancipatory struggle. I will then provide an analysis of state and bourgeois control through the discourse of rights with an emphasis on the class conflict. I will make extensive use of examples including the mandate of the G-20 protests and the recent struggles in the Paris suburbs. Using the theoretical concepts of Benjamin, Zizek, Virilio and Sorel I will discuss divine and mythical violence in relation to the emancipatory struggle and the spectacle of the protest demonstrating the strength of the solidarity of the people. [Article copies available for a fee from The Transformative Studies Institute. E-mail address: journal@transformativestudies.org Website: http://www.transformativestudies.org (02011 by The Transformative Studies Institute. All rights reserved.]

KEYWORDS: Human Emancipation, The Spectacle, Divine Violence.

\footnotetext{
${ }^{1}$ Address correspondence to: Madison Trusolino; e-mail: madisontrusolino@gmail.com.
} 